\title{
Application of costing methods: a case study in a retailer in the Triângulo Mineiro
}

\author{
Alexsandro Silva Solon¹, Fernando Araújo², Flavia Brito Araújo \\ ${ }^{1}$ Federal University of Triângulo Mineiro - UFTM, Uberaba, MG, Brazil. \\ ${ }^{2}$ Federal University of Catalão- UFCAT, Catalão, GO, Brazil. \\ ${ }^{3}$ Federal University of Uberlândia - UFU, Uberlândia, MG, Brazil.
}

How to cite: Solon, A.S., Araújo, F., and Araújo, F.B. (2021), “Application of costing methods: a case study in a retailer in the Triângulo Mineiro", Brazilian Journal of Operations \& Production Management, Vol. 18, No. 1, e2021895. https://doi.org/10.14488/BJOPM.2021.006

\section{ABSTRACT}

Goal: The aim of this article is to show the importance of applying costing methods to increase the contribution margin and decision-making, besides helping the company to become more competitive against competitors.

Design / Methodology / Approach: This study carried out a case study of a quantitative nature, based on bibliographic works. He employed a semi-structured interview. The Direct / Variable Costing method was used to recognize points that could be improved. In addition, the data was organized into spreadsheets in the Office package.

Results: The results of the survey show at the end of the action survey that the company chose to outsource the raw material from its second item of highest revenue: cheese bread. With the change, the item increased its contribution margin by $30.16 \%$ and reduced costs by $77.98 \%$, increasing the company's profit, reducing the product's equilibrium point from $54.14 \%$ to $4.14 \%$ of average daily production.

Limitations of the research: As limitations of the study, we highlight that the company passed on the already established costs for some products, so the costs were calculated considering this percentage.

Practical Implications: Its practical implications are to demonstrate the importance of the relationship between costs and sales price as a decision-making strategy.

Originality / Value: The study contributes to the academic area and adds knowledge related to costs and sales price for the bakery sector, being useful for users and interested in the bakery sector and its costs.

Keywords: Costing Methods; Bakery; Equilibrium Point; Contribution Margin.

\section{INTRODUCE}

The changes that occurred in the urbanization process have stimulated society's behavior and preferences regarding food consumption (Associação Brasileira da Industria de Panificação e Confeitaria, 2017). The food sector is related to the cost of living, in addition to being relevant to the global economy (Konstantas et al., 2019). In this sense, SEBRAE (SERVIÇO BRASILEIRO DE APOIO ÀS MICRO E PEQUENAS EMPRESAS, 2017) reported that economic issues and changes in the population's income become one of the determinants for the population's decision making. In this context, the Brazilian Institute of Geography and Statistics (IBGE) recognizes the importance of retail trade. The retail sector is responsible for the largest number of employees $(7,889)$, about $73.7 \%$ of

Financial support: None.

Conflict of interest: The authors have no conflict of interest to declare.

Corresponding author: alex_solon@hotmail.com

Received: 18 Sep 2019.

Approved: 2 Nov 2020

Editor: Osvaldo L. G. Quelhas and Julio Vieira Neto. 
the total, and for the largest number of companies $(1,298)$, with $78.8 \%$ of the total. In relation to net operating revenue, the retail segment accounts for $43.4 \%$ of revenue (Instituto Brasileiro de Geografia e Estatística, 2017). The retail of food products includes bakery companies that comprise bakeries and confectioneries. The bakery sector stimulates the increase in the retail food revenue and is among the six largest industrial segments in the country and the second in ready-to-eat foods (Rocha et al., 2019).

In 2017, the Technological Institute of Bakery and Confectionery (Instituto Tecnológico de Panificação e Confeitaria, 2018) followed around 400 companies from 19 Brazilian states and reported a $3,2 \%$ projection in sales (without discounting inflation) which corresponds to $R \$$ 90.3 billion. It is important to note that, in general, more developed regions attract more capital and qualified labor than regions with less development (Hirschman, 1958). In Brazil, economic development in the Brazilian scenario is concentrated in the Southeast regions (Associação Brasileira das Entidades dos Mercados Financeiro e de Capitais, 2020). Thus, the states of Rio de Janeiro and São Paulo have the largest number of bakeries and Minas Gerais registered in 2018 the 3rd place with 7,100 bakeries, (Associação Brasileira das Entidades dos Mercados Financeiro e de Capitais, 2018a).

The segment has stimulated strategies associated with its own manufacture, which corresponds to the second place among the indicators of highest revenue in the sector, with approximately $64 \%$ of sales or R $\$ 57.79$ billion, on the other hand, resale items represented $36 \%$ of sales (equivalent to $\mathrm{R} \$ 32.5$ billion) in 2017 (Instituto Tecnológico de Panificação e Confeitaria, 2018).

This scenario has enabled an impact on economic changes, customer behavior, on increasing competition with new entrants, as well as on growing revenue from products manufacturing by the company (Associação Brasileira da Industria de Panificação e Confeitaria, 2018c). The sector is very competition, but many establishments offer the same service without much distinctions, such as supermarkets which are the main competitors (Roncato, 2015). The Brazilian Association of the Bakery and Bakery Industry (Associação Brasileira da Industria de Panificação e Confeitaria, 2018b) pointed out that compared to the supermarket sector, bakery and confectionery companies indicated higher growth, and recorded a $2 \%$ increase in sales in the period from January to December 2017.

Data from the Department of Research and Economic Studies (DEPEC) of 2017 evidenced the relevance of the participation of perishables sections with $40.9 \%$ in Brazilian gross revenues, with $4.5 \%$ expressiveness in the Bakery and Rotisserie items. Therefore, Figure 1 shows the participation data per billing section for 2016 .

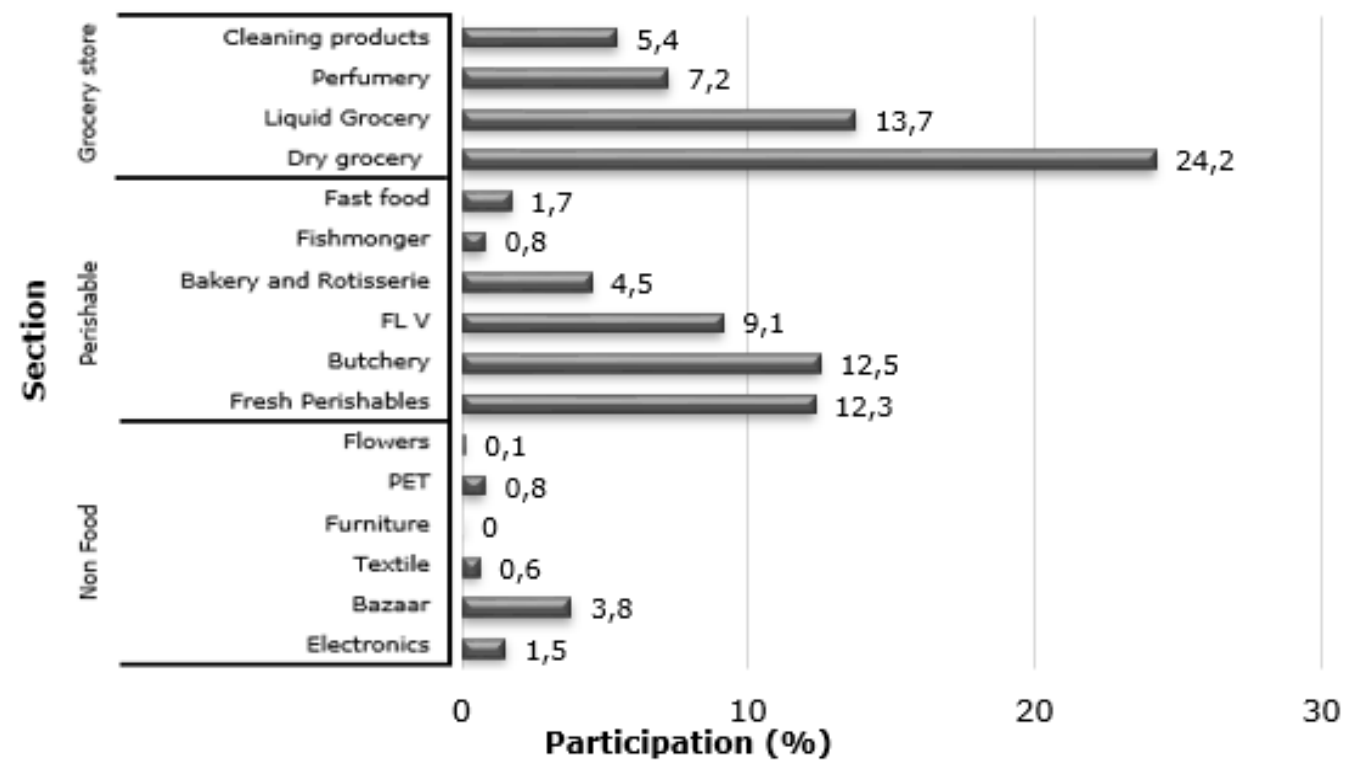

Figure 1 - Participation of the sections in the gross sales of Brazilian supermarkets in 2016 Source: Adapted from Departamento de Pesquisa e Estudos Econômicos (2017). 
SEBRAE (Serviço Brasileiro de Apoio às Micro e Pequenas Empresas, 2017) emphasizes that the initial investment in the bakery sector is considered low, allowing new entrepreneurs to invest in this segment. To obtain differentiation in the face of competition, the creation and offer of new products and services and determine which areas and products should be invested, it is necessary to have in hand a financial control of costs that presents the financial return that the product or service will provide. For Porter (1989) to execute activities of strategic relevance cheaply or better than competition is what makes the company gain competitiveness. Thus, costing methods provide management information crucial for managers' decision-making, to obtain profits and achieve the previously outlined objectives, becoming an essential tool to determine costs and apply them more precisely (Carareto et al., 2006; Rocha et al., 2019). In addition, Corrêa and Corrêa (2012) stressed that it is necessary to choose the company's priorities to direct the efforts of operations and the critical points to be improved.

Considering this scenario, this article aims to demonstrate the importance of applying costing methods to increase the contribution margin as a relevant element for management decision-making, and finally, to help the company to become more competitive against competitors. Under this context, this article conducted a case study of a bakery inside the Triângulo Mineiro, in this is the first few months of 2017, as it identified a drop in sales. The choice was motivated due to the owner seeking help, after presenting a drop in sales in three consecutive months, which allowed access to the information to achieve the proposed objectives. In addition, the bakery sector showed significant growth in the country.

To achieve the main objective, the following specific objectives were outlined: i) to identify the main items from Pareto analysis; (ii) identification of the unit costs of the products and raw material; (iii) identify and demonstrate the contribution margin of the product; and (iv) present the equilibrium point. Moreover, the research seeks to add knowledge related to the theme and contribute to the academic and practical area, being useful for users and interested parties about bakery and its costs, in order due to demonstrate the importance of the relationship between costs and sales price.

This case study is relevant, given that the retail sector has the largest share in the number of companies and in the occupation of work sources. It covers the bakery sector, a market that is in a process of saturation due to the poor distribution of organizations in various regions of the country, which increases the dispute for the local public. And as strategies to remain competitive, they invest in the diversification of products and services in a structured way, combined with the dilution of indirect costs, to compete with fairer prices, in addition to strategies of high quality and convenience (Associação Brasileira da Industria de Panificação e Confeitaria, 2017).

We seek to contribute to the literature by presenting a case study that deals with the regional scenario, in order to analyze the bakery sector in the city of Ituiutaba in the mining triangle, since according to data from the Technological Institute of Bakery and Confectionery (ITPC) from the point of view practical, consumers visit the point of sale on average 14 times a month. It also highlights the need to plan the best strategy, develop new services and generate innovation in the market, as bakeries become gastronomic hubs, with a diversified mix that deserves to be highlighted.

\section{THEORETICAL FRAMEWORK}

\section{Management of operations as a competitive strategy}

Moreira (2008) defines Production and Operations Administration as the field of study of concepts and techniques applied to decision-making, concerned with the planning, organization, direction, and control of productive activities, to direct them to achieve the company's objectives.

Within this context, Corrêa (2012) discusses the concept of operations strategy from a perspective, where they act proactively and long-term, having in operations not the function 
of serving other sectors of the company, but to maximize its contribution to achieve competitive advantage and the purposes of the organization.

Hayes and Wheelwright (1984) define four stages of the strategic position of operations: internal neutrality, external neutrality, internal support and external support, and these evolve from the former, where they seek not to disturb the rest of the company's sectors until the latter, where the company now has competitiveness based on manufacturing. The authors explain that in external neutrality institutions seek to at least equate themselves with competitors.

Corrêa and Corrêa (2012) recognizing the levels at which operations can act, discusses focused operations, claiming that to support the business strategy the function of operations must perceive the system as a set of volumes, markets and limited technologies, establishing priorities to be improved by the organization.

Slack (1993) from this perspective points out that improving the performance of a priority compromises the performance of another priority, dynamics like the behavior of a seesaw. Corrêa and Corrêa (2012) on this dynamic explains that it is possible to recover the performance sacrificed without losing the recently acquired improvement. Figure 2 exemplifies the seesaw movement defined by Slack: in a) by improving the performance of priority 1 , the performance of 2 is lost; in b) the same occurs for priority 2; (c) the possibility of balancing the two priorities is shown.

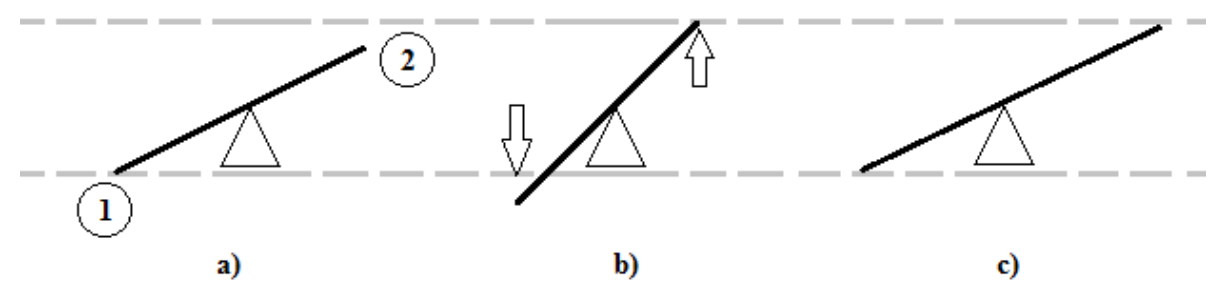

Figure 2 - Seesaw movement in improving priority performance.

Source: Adapted from Corrêa and Corrêa (2012)

For Corrêa and Corrêa (2012) it is necessary to choose the priorities of the company to direct the efforts of operations and the critical points to be improved. To better understand the decision-making process, the author is based on Hill's definitions (Hill, 1985) on the concepts of qualifying criteria and order winners. Qualifiers are criteria where performance must have minimal performance for the product or service to be considered by the customer. The winning criteria are those on which the customer will rely to choose from the qualified suppliers.

In operations management, once priorities are defined, one should keep in mind which decision-making area will be subject to improvement efforts. Decision areas, among others: product/service design, facilities, capacity/demand, quality, supply and operations networks, performance metrics and production planning and control systems (Corrêa and Corrêa (2012)).

Regarding demand characteristics and service level, Teller et al. (2018) highlight that greater demand volatility decreases the costs of stationary inventory policies. However, there is a need to be analyzed in greater detail.

Moreover, Teller et al. (2018) point out that for there to be conditions of balance, from the point of view of retail patterns, developments depend on the moment, location and different types of stores (such as international stores, supermarkets and online ecommerce), in addition to two main factors. The first are the characteristics of consumers, such as income, tastes, and travel costs of different stores. It stands out that in previous years the falls in the retail sector are the result of the weakening of the labor market and the uncertainties arising from the economic environment that contributed to the reduction of household consumption and, consequently, retail sales (Departamento de Pesquisa e Estudos Econômicos, 2017). 
The second factor concerns store cost structures, which include upstream producer cost items, purchasing supply chain costs (in addition to the item cost) for perishable items, and store storage costs (Lu and Reardon, 2018). In addition, waste represents a significant issue affecting the stages of the supply chain, including retail (Teller et al., 2018).

In this sense, a retail store represents the point of separation of orders from a supermarket supply chain; is the place where consumer demand meets the retailer's offer in terms of product quality and quantity (Teller et al. 2018).

\section{Value Chain and Outsourcing}

For Porter (1989) the value chain dismembers the company's strategically relevant activities to understand its behavior and costs, as well as its potentialities. The author argues that performing activities of strategic relevance cheaply or better than competition is what makes the company gain competitiveness.

CARELLI, (2004) defines outsourcing as a transfer of activities by the company to suppliers that have in these end-activity, freeing efforts for its main business, generating with this act cost reduction and gains in quality and efficiency compared to competitors.

In this sense, Corrêa and Corrêa (2012) speaks about the point at which outsourcing creates value for the network, not only appropriation of value created by its suppliers. The author argues that, based on academic terms, if outsourcing implies a lower cost than performing the activities in question internally, the indication would be to outsource.

\section{Pareto analysis: quality in the identification of critical operations}

Moreira (2008) conceptualizes conformation quality as the set of attributes of a product or service that have a lower or higher degree of performance relating (to) the established standards and specifications.

The compliance level can be measured with Pareto analysis. Able to identify the few critical elements relating (to) the whole, it shows that $20 \%$ of the final effect comes from $80 \%$ of the causes. The analysis aims to highlight critical resources and operations so that improvement efforts can be properly directed (Corrêa and Corrêa (2012)).

Walton (1989) states that improving quality implies lower costs, which increases productivity, lowering the price and making it easier for the company to stay in business.

In this sense, improving the control of the values used in the production of its products and execution of its services can be pointed out as one of the main motivators for the emergence of cost accounting, capable of directing and avoiding excess expenses and supporting the decision-making process (Martins, 2008; Rocha et al., 2019).

In addition, organizations that have good cost control can monitor their business performance, and relate the results obtained as consequences of good cost management (Lima, 2014).

\section{Costs}

Product costs can be the most influenced in the early stages and decreasing degrees of the product, so they are important to be only the domain of cost estimation and industrialization. In addition, it influences management's decision-making through cost information to set product prices, decide on the product mix, well as in the planning and control of the manager (Hundal, 1997).

Accounting has as its main point the calculation of unit costs, being of paramount importance at the managerial level for the parameterization of the unit sales price of the product or service to be offered (Padoveze, 2015).

Regarding the terminologies, Bruni and Famá (2010) state that the correct understanding and calculation of costs and price formation are: 
- Spending: represents the financial sacrifice the company has to obtain a product or service, which can be classified as investments, costs or expenses;

- Investments: investments according to their useful life or benefits attributable to future periods;

- Costs: expenses related to goods or services used in the production of other goods or services, such as, for example, labor, packaging, raw materials, among others;

- Expenses: they are not associated with the process of transforming a product or service. They are related indirectly to obtain revenue. As examples, administrative spending and salaries of sales people.

Also, according to Bruni and Famá (2010) costs and expenses differ to the extent that costs are directly related to the manufacturing process and expenses are more associated with administrative expenses. As such, retail chains try to minimize costs in any way (Holý et al., 2017).

From the manufacturing costs, it is possible to make decisions about a product to decide whether to be phased out, or even determine the quantities of each product to be made to maximize resource utilization (Hundal, 1997).

Considering the need to associate expenditures with manufactured products, Bruni and Famá (2010) classify costs in terms of applicability and volume variability:

- Applicability:

o Direct or primary: they have the property of being perfectly measurable objectively.

o Indirect: they need approximations, that is, some apportionment criterion.

o Transformation: consist of the effort added by the company in obtaining the product.

- As for volume variability:

o Fixed: exist even if there is no production.

- Variables: its total value changes directly depending on the company's activities.

- Semi-fixed: correspond to fixed costs up to a certain level, becoming variable as this level is exceeded.

- Semi variates: variable costs that do not linearly follow the production variation, but to the jumps, remaining fixed within certain limits.

Figure 3 shows the evolutionary behavior of the costs with the volume produced. Fixed, variable, semi-fixed, semi-variable costs are represented respectively by a), b), c) and d).

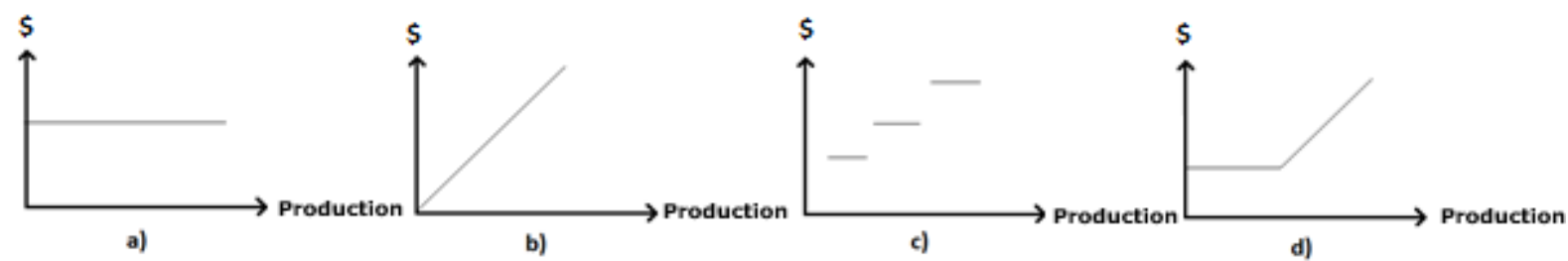

Figure 3 - Classification of costs for production volume.

Source: Adapted from Bruni and Famá (2010)

Dutra (2010) defines total cost (TC) that formed by the sum of the total fixed costs (CF) and variables (CV). Figure 4 exemplifies the generic behaviors of costs as to the quantity produced. 


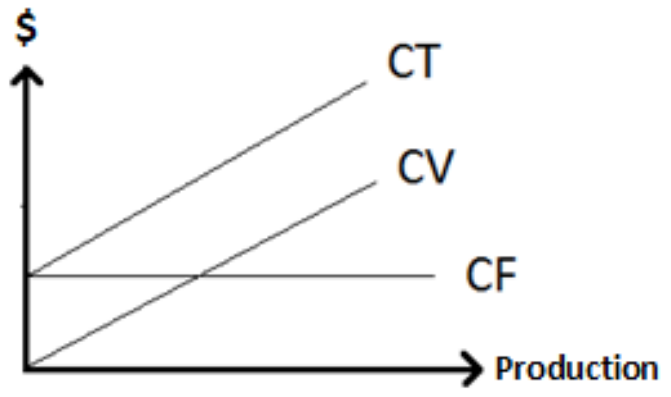

Figure 4 - Total costs depending on production. The total cost is the sum of the fixed and variable costs

Source: Adapted from Dutra (2010)

According to Dutra (2010) unit costs result from the division of total costs by the volume produced. The total (global) cost is defined by Equation 1. The total fixed cost is defined by Equation 2. The total variable cost is defined by Equation 3.

$C T=c t \times Q$

$C F=c f \times Q$

$C V=c v \times Q$

Where,

$C T=$ total cost (global);

$C F=$ total fixed cost;

$\mathrm{CV}=$ total variable cost;

$c t=$ total unit cost;

$c f=$ unit fixed cost;

$c v=$ unit variable cost;

$Q=$ quantity produced.

Therefore, costs have significant impacts on retail store operations on retailers' profits and services, becoming key success factors in the food industry (Reiner et al., 2013).

\section{Costing Methods}

Costing methods are crucial procedures in the production of information for decisionmaking, so it is necessary for each organization to know the costing method that best fits its needs (Rocha et al., 2019).

Padoveze (2015) defends the costing method as a process of identifying the unit cost of a product or service based on total indirect or direct costs. It also points out that the definition of each method comes from the types of expenditures considered for costing.

Thus, the main costing methods and their relevant expenses are evidenced in Table 1.

The Direct/Variable Costing method is considered by Padoveze (2015) to be the best scientifically, for treating labor as a variable cost and bringing with it the concept of contribution margin. According to the author, the contribution margin indicates how much each unit produced contributes to the absorption of fixed costs and expenses, since such margin is the difference between the selling price and the direct/variable costs. Being P, sales price, and, total variable cost, Equation 4 evidences the author's definition. 
Table 1 - Costing methods and their expenses considered

\begin{tabular}{|c|c|c|c|c|c|}
\hline \multirow[b]{2}{*}{ Types of Expenses } & \multicolumn{5}{|c|}{ Costing Method } \\
\hline & $\begin{array}{c}\text { Theory of } \\
\text { Restrictions }\end{array}$ & $\begin{array}{l}\text { Direct/Varia } \\
\text { ble Costing }\end{array}$ & $\begin{array}{l}\text { Absorption } \\
\text { Costing }\end{array}$ & $\begin{array}{c}\text { ABC Costing } \\
\text { (Integral) }\end{array}$ & RKW \\
\hline \multicolumn{6}{|c|}{$\begin{array}{l}\text { Raw material, direct materials, and } \\
\text { packaging }\end{array}$} \\
\hline \multicolumn{6}{|l|}{ Variable expenses } \\
\hline \multicolumn{6}{|l|}{ Direct labor } \\
\hline \multicolumn{6}{|l|}{ Indirect labor } \\
\hline \multicolumn{6}{|l|}{ Industrial overheads } \\
\hline \multicolumn{6}{|l|}{ Depreciation } \\
\hline \multicolumn{6}{|c|}{ Administrative/commercial labor } \\
\hline \multicolumn{6}{|l|}{$\begin{array}{l}\text { Administrative/commercial } \\
\text { expenses }\end{array}$} \\
\hline Financial expenses & & & & & \\
\hline
\end{tabular}

Source: Adapted from Padoveze (2015)

Moreover, the costing methods, according to Cardoso et al. (2017) are complementary because it is possible to identify how much the market is willing to pay for the product or service. If the price of the product is higher than the costs of the product, the market would be paying inefficiencies of the process, however, if it is below the absorption it would be ideal then one should rethink the process.

\section{Expenses of the Direct/Variable Costing method}

The personnel and material expenses of Direct/Variable Costing will be defined below, explaining what it is necessary to consider sizing them correctly.

Material is a component that can be benefited by turning into another very different one throughout the production process. Its classification of applicability and variability is relative and depends on the context of each company, with its particularities. However, the material can be subdivided into direct raw material, indirect raw material, auxiliary materials, packaging materials, among others (Dutra, 2010).

Dutra (2010) explains about personnel expenses that these can be classified as direct labor and indirect labor. The first is defined as the representation of personnel directly involved in production, being able to easily count how long each worker has in the transformation of a product or service. The second is represented by personnel whose office is impossible to measure in terms of the unit produced at the time they work. It is also indicated by the author that personnel expenses include direct compensation, social contributions, labor charges, indirect remuneration and benefits granted.

\section{Pricing and profit analysis}

The sales price of a product is not defined exclusively from costs, as it is also influenced by supply and demand, considering the issue of competition (Padoveze, 2015). In this sense, market competition is caused by several factors that occur within organizations, so there is a need for organizations to look for strategies that make them differentiated in the face of competition. Thus, one of the strategies used is related to the organization's pricing policy (Rocha et al., 2019).

Cost accounting acts as a tool in the price formation process, avoiding excess expenses and subsidizing the decision-making process (Rocha et al., 2019). In this way, the methods of price formation, according to Bruni and Famá (2010), can be based on costs, competition or 
the consumer. The cost-based method is further subdivided into: full cost-based pricing, costbased transformation prices, marginal cost-based pricing, prices based on the required rate of return on invested capital, and prices based on standard cost. In the pricing model based on the standard cost it is necessary to correctly separate the variable costs, assigned to the product, from the operating costs belonging to the company (Bruni and Famá, 2010).

In this context, the formation of the sale price of products and services determines the success or failure of the organization as a crucial activity, because by wrongly setting a price it can cause damage to the organization (Bruni and Famá, 2010). In addition, it is important that the company knows the cost of manufacturing, as it is the main factor that influences the total cost. Therefore, the company can better know whether the product can be manufactured at a profit and therefore at what price it should be sold (Hundal, 1997).

In this context, the main objectives of the price formation process, according to Assef (2010) and Bruni and Famá (2010) highlighted that the decision in the formation of prices is related in providing, the success of the company, in the biggest possible profit, allowing the maximization of the market share; maximize and enhance productive capacity by minimizing idleness and operational waste.

\section{Balance Point}

Padoveze (2015) defines equilibrium point as the volume needed to be sold by the company to cover all fixed and variable expenses related to the product, and after this point, the products sold become profit. Dutra (2010) states that the balance point amount (Eq) is the difference between the fixed cost and unit contribution margin of the product. Being $P$, sales price, and unit variable $c v$ cost, Equation 5 demonstrates the calculation of the equilibrium point.

$$
E q=\frac{C F}{P-c v}
$$

Dutra (2010) when analyzing the equilibrium point equation, considering the amount produced, realizes that the lower the $E q$, the greater the profit. Figure 5 shows the behavior of spending relating (to) revenue, exemplifying the balance point and the areas of loss (red) and profit (green).

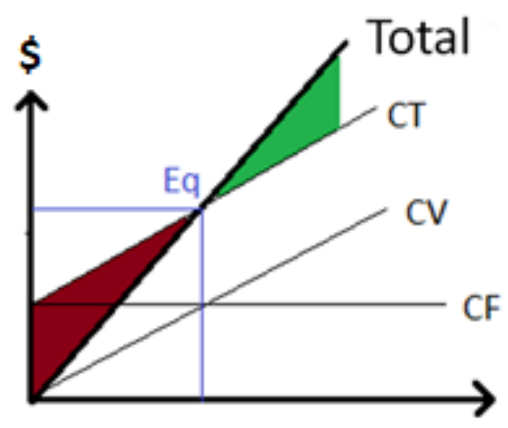

Figure 5 - Balance Point.

Source: Adapted from Dutra (2010)

\section{CASE STUDY}

In the municipality of Ituiutaba, in the Region of triângulo Mineiro, the retailer studies have been operating for more than 20 years, being a local reference in bakery items. After showing a drop in sales in three consecutive months, the owner sought help from the educational institution, and with the help of a Production Engineering intern, identified critical products that were not with the expected financial return. 
It is noteworthy that the contribution of Small and Medium Enterprises in the world economy is enormous (Jeje, 2020). In addition, the bakery sector has been growing and has shown increases in revenue and own production and is among the six largest industrial segments in the country and second in ready-to-eat foods (Rocha et al., 2019). Moreover, own production sales accounted for $64 \%$ of the turnover, or $\mathrm{R} \$ 57.79$ billion, while resale items accounted for $36 \%$ of revenues (equivalent to $\mathrm{R} \$ 32.5$ billion) in 2016 (Associação Brasileira da Industria de Panificação e Confeitaria, 2018b).

Given this context, the current scenario of organizations is determined by competition, caused by several factors that occur within companies, leading to the need for strategies that differentiate them from competitors. Thus, one of the strategies adopted is related to the organization's pricing policy (Rocha et al., 2019). On the other hand, one of the challenges of Globalized economies are associated with keeping costs and investments low, reducing losses, optimizing the purchase of inputs, discontinuing stagnant products, and selling nonproductive assets (Carareto et al., 2006).

Thus, Carareto et al., (2006) highlight that production cost methods offer different cost views that allow meeting the needs of each user in a competitive, strategic, operational, and financial way. In moreover, cost/volume/profit analysis and application of mechanisms such as contribution margin, accounting balance point and operational leverage are tools that contribute significantly to decision-making.

To develop this study, the first step was to obtain the bakery sales data for the first six months of 2017 and then perform the Pareto analysis to identify the most important items. Sixty-eight items were produced in this period, 7 of which represent $80.86 \%$ of the revenue. Table 2 shows billing and related items between January and June.

Table 2 - Pareto analysis of items produced by the bakery between January and June 2017

\begin{tabular}{cccccc}
\hline Item & R\$ & Kg & $\begin{array}{c}\text { Relative } \\
\text { Percentage }\end{array}$ & $\begin{array}{c}\text { Cumulative } \\
\text { Percentage }\end{array}$ & $\mathbf{R} \$$ Accumulated \\
\hline French Bread & $\mathrm{R} \$ 229,036.90$ & $21,868.17$ & $58.69 \%$ & $58.69 \%$ & $\mathrm{R} \$ 229,036.90$ \\
\hline Cheese Bread & $\mathrm{R} \$ 38,668.99$ & $1,760.40$ & $9.91 \%$ & $68.60 \%$ & $\mathrm{R} \$ 267,705.89$ \\
Broa of Corn meal & $\mathrm{R} \$ 13,362.01$ & 957.21 & $3.42 \%$ & $72.02 \%$ & $\mathrm{R} \$ 281,067.90$ \\
\hline Sweet Sprinkle Biscuit & $\mathrm{R} \$ 10,098.33$ & 598.16 & $2.59 \%$ & $74.61 \%$ & $\mathrm{R} \$ 291,166.23$ \\
\hline Condensed Milk Thread & $\mathrm{R} \$ 9,126.93$ & 537.87 & $2.34 \%$ & $76.95 \%$ & $\mathrm{R} \$ 300,293.16$ \\
Nest Milk Bread & $\mathrm{R} \$ 7,822.00$ & 652.70 & $2.00 \%$ & $78.95 \%$ & $\mathrm{R} \$ 308,115.16$ \\
\hline Bread of Form & $\mathrm{R} \$ 7,460.91$ & $1,359.00$ & $1.91 \%$ & $80.86 \%$ & $\mathrm{R} \$ 315,576.07$ \\
\hline Other & $\mathrm{R} \$ 74,681.34$ & $6,456.59$ & $19.14 \%$ & $100.00 \%$ & $\mathrm{R} \$ 390,257.41$ \\
\hline Total & $\mathrm{R} \$ 390,257.41$ & $34,190.09$ & & & \\
\hline
\end{tabular}

Source: Company-provided data (2017)

After the analysis, it was noticed that the items French bread and cheese bread add up to approximately $68.60 \%$ of the revenue. The owner of the bakery informed not knowing the actual cost of the production of cheese bread, therefore, due to its importance in the bakery sales, it was then carried out its costing.

However, it is noteworthy that referring to the general scene the volume of production of companies decreased by $70 \%$ in the quantity manufactured of the main product, which is French bread. As regards revenues, $60 \%$ of companies registered a fall (Associação Brasileira da Industria de Panificação e Confeitaria, 2018b).

\section{Cost of cheese bread item}

To find the cost of cheese bread, the Direct/Variable Costing Method was used with stages of: observation of the preparation of the recipe for annotation of the use of raw material of 
cheese bread, calculation of direct labor, energy expenditure and obtaining data related to variable expenses.

According to the company the operating costs correspond to an additional $10 \%$ of the value of each raw material used in the bakery, therefore, the costs of the ingredients were calculated considering this percentage more. The variable expenses with packaging and cleaning material of the utensils used in the kitchen, also according to the company, correspond to about $5 \%$ of the cost of the items it produces.

\section{Raw material and energy costs}

After observing the preparation of the cheese bread recipe, the average cost of the ingredients, raw dough and baked cheese bread was obtained, considering that throughout the preparation there are losses inherent to the process such as dehydration of the dough and unused leftovers in the utensils and forms used.

Thus, for Teller et al. (2018) food waste in retail represents an important commercial issue, given the low overall margins on food products and the increasing operating costs, as the store level represents a significant issue affecting all stages of the supply chain, including retail.

During the study it was detected that the yield and costs per kilo of cheese bread is on average $7.46 \mathrm{~kg}$ average and $\mathrm{R} \$ 7.32 \mathrm{per} \mathrm{kg}$. The mass presented $8.54 \mathrm{~kg}$ of average ingredients and value of $\mathrm{R} \$ 7.73$ per $\mathrm{kg}$. And the roast presented $7.46 \mathrm{~kg}$ and $\mathrm{R} \$ 7.93$ per $\mathrm{kg}$.

Considering the cost of $\mathrm{kW} / \mathrm{h}$ of the establishment and knowing the time spent in the mixer and oven, and its respective powers of $0.37 \mathrm{~kW}$ and $16.00 \mathrm{~kW}$, Table 3 was elaborated with the approximate cost of energy used in the preparation of cheese bread. It is noteworthy that the cost of energy is variable in the general scope of the bakery, but fixed when observed for cheese bread, since to prepare the dough of a recipe the equipment supports up to $15 \mathrm{~kg}$, requiring 13 minutes in the mixer and 25 minutes spent with the oven, no matter if $7 \mathrm{~kg}$ or $15 \mathrm{~kg}$ of dough will be made.

Table 3 - Fixed energy cost in the preparation of cheese bread

\begin{tabular}{cccc}
\hline Equipment & $\mathbf{R} \$ \mathbf{1} \mathbf{~ k W / m i n}$ & Weather $(\mathbf{m i n})$ & Total Cost $\mathbf{R} \mathbf{\text { ) }}$ \\
\hline Mixer & $\mathrm{R} \$ 0.0042$ & 13 & $\mathrm{R} \$ 0.0545$ \\
\hline Oven & $\mathrm{R} \$ 0.1813$ & 25 & $\mathrm{R} \$ 4.5333$ \\
Total & & 38 & $\mathrm{R} \$ 4.59$ \\
\hline
\end{tabular}

Source: Data obtained by the authors

\section{Manpower}

It was noticed that the micro activities of cheese bread preparation are carried out alternately and not planned by the four employees of the bakery kitchen. In addition, the internal dynamics of operation causes the preparation of the item to be stopped several times, being for the level of urgency required by the owner, it is not feasible to calculate the actual time per employee, on average, used in the preparation from start to finish. For this reason, the labor cost, although it is of a direct nature, was considered for calculations as fixed, characterizing itself as necessary regardless of the amount produced of cheese bread. Table 4 shows the hourly cost of each employee considering their respective additional charges, charges, and base salary for each role.

Table 4 - Labor costs in the preparation of cheese bread

\begin{tabular}{cccccc}
\hline Employee & Base Salary & Additional & Charges & Total Cost & Time Value \\
\hline Baker 1 & $\mathrm{R} \$ 1,279.00$ & $\mathrm{R} \$ 919.46$ & $\mathrm{R} \$ 853.99$ & $\mathrm{R} \$ 3,052.45$ & $\mathrm{R} \$ 13.87$ \\
\hline $\begin{array}{c}\text { General } \\
\text { Services }\end{array}$ & $\mathrm{R} \$ 997.00$ & $\mathrm{R} \$ 291.59$ & $\mathrm{R} \$ 665.70$ & $\mathrm{R} \$ 1,954.29$ & $\mathrm{R} \$ 8.88$ \\
\hline $\begin{array}{c}\text { Baker's } \\
\text { Helper }\end{array}$ & $\mathrm{R} \$ 997.00$ & $\mathrm{R} \$ 201.20$ & $\mathrm{R} \$ 665.70$ & $\mathrm{R} \$ 1,863.90$ & $\mathrm{R} \$ 8.47$ \\
\hline Baker 2 & $\mathrm{R} \$ 1,657.00$ & $\mathrm{R} \$ 933.05$ & $\mathrm{R} \$ 1,106.38$ & $\mathrm{R} \$ 3,696.43$ & $\mathrm{R} \$ 16.80$ \\
\hline
\end{tabular}

Source: Company-provided data (2017) 


\section{Final cost}

Once the necessary data were obtained with the Direct/Variable costing method, it was possible to elaborate Table 5 with the final costs of preparing the item. It is noticed that the total variable cost of cheese bread is $R \$ 12.01$ and the total fixed cost is $R \$ 52.62$, with the overall cost of $R \$ 64.63$.

Table 5 - Fixed and variable expenses of cheese bread

\begin{tabular}{cccc}
\hline Expenditure & Value & Type & Unit \\
\hline Ingredients & $\mathrm{R} \$ 8.93$ & Variable Cost & $\mathrm{R} \$ / \mathrm{kg}$ \\
\hline Energy & $\mathrm{R} \$ 4.59$ & Fixed Cost & $\mathrm{R} \$$ \\
\hline Manpower & $\mathrm{R} \$ 48.03$ & Fixed Cost & $\mathrm{R} \$$ \\
\hline Miscellaneous materials & $\mathrm{R} \$ 3.08$ & Variable expense & $\mathrm{R} \$ / \mathrm{kg}$ \\
\hline
\end{tabular}

Source: Data obtained by the authors

\section{Strategic outsourcing decision: frozen cheese bread}

Considering the cost of cheese bread and knowing that there is in the market the offer of several brands of frozen cheese breads, the owner of the bakery made the decision to outsource the production of the item. One of the suppliers was chosen for their regional reference, whose cost per kilo is $\mathrm{R} \$ 9.00$ being sold in $2 \mathrm{~kg}$ packages, which will be delivered daily according to the need of the bakery.

With the change in the production system was opted to use a smaller oven with the capacity to bake up to one package of $2 \mathrm{~kg}$ at a time. Its power of $2.56 \mathrm{~kW}$ raises a cost of $\mathrm{R} \$$ 0.73 for each 25 -minute batch required in the preparation.

It was also determined that the general services' employee would be responsible for putting the frozen cheese bread to bake, watch its preparation and remove it as soon as it was ready for the sales area. Based on Table 5, the cost of each minute of your labor is calculated: $\mathrm{R} \$ 0.15$. The time spent is 25 minutes while the item is snaking and 5 minutes for preparation and delivery to the sales area.

Thus, the new fixed total cost is $R \$ 5.23$ and the total variable cost becomes $R \$ 9.00$ per kilo, totaling an overall cost of R\$14.23. The new expenses are evidenced in Table 6.

Table 6 - Fixed and variable expenses with frozen cheese bread

\begin{tabular}{cccc}
\hline Expenditure & Value & Type & Unit \\
\hline Frozen cheese bread & $\mathrm{R} \$ 9.00$ & Variable Cost & $\mathrm{R} \$ / \mathrm{kg}$ \\
\hline Energy (oven) & $\mathrm{R} \$ 0.73$ & Fixed Cost & $\mathrm{R} \$ / \mathrm{g}$ \\
\hline Manpower & $\mathrm{R} \$ 4.50$ & Fixed Cost & $\mathrm{R} \$$ \\
\hline
\end{tabular}

Source: Data obtained by the authors

\section{METHODOLOGY}

This stage of the work describes the methods used for the development of the study, which is a driver of the analysis. First, this article consists of a case study of a quantitative nature, based on scientific research of an applied nature, based on a scientific research of an applied nature, which according to Prodanov and Freitas (2013) aims to generate knowledge for practical application directed to the solution of specific problems, involving local interests.

This study conducted a theoretical study, based on bibliographical works, to play an active role in solving the problem addressed and characterize the reality in which researchers are involved (Prodanov and Freitas, 2013).

\section{Data Collection}

The data collected are records and a company from Ituiutaba -MG, with cost information about their products and procedures used for production. The access to such documents 
occurred through the company's manager-administrator, through a semi-structured interview, which according to Roesch (2003) the interviewee speaks freely, which allows a higher level of information. At this stage, the activities carried out in the development of the research followed the following steps:

- Data collection: Retailer - Municipality of Ituiutaba (Triângulo Mineiro).

- $\quad$ Period: First six months of 2017;

- Tools: Pareto Analysis, Direct/Variable Costing Method, Raw Material and Energy Costs, Labor and Margin contribution.

It is noteworthy that Barbosa et al. (2007) used the arithmetic mean of three sites in the six-month period (January to June 2004) to calculate feeding costs in the first year of life.

\section{Data Analysis}

In this phase, the bakery sales data were collected and from Pareto analysis the most important items were identified between January and June 2017, followed by the other tables to detect costs and expenses.

According to Carareto et al. (2006) the costing method has an advantage because it allows the identification of the most profitable products to the company. In addition, Wernke (2017) pointed out that absorption costing is the most appropriate method, as it meets the legislation and fundamental principles of accounting, due to accounting purposes, in addition to actually evaluating product costs. It is noteworthy that the method does not consider the expenses integral to the inventories of goods and services, but all the costs applied in obtaining them, thus enabling the calculation of results, calculations of taxes and dividends to be distributed, since they absorb all production costs (fixed, variable, direct or indirect), in addition to aggregating the cost of products for valuing inventories (Carareto et al., 2006; Wernke, 2017).

Subsequently, the interpretation of the data was made to elaborate an improvement plan intending to remedying the problems encountered and making the company more competitive against competitors, in addition to verifying the relationship on the analysis for outsourcing implementation and the calculation of the new cost of the product. Cost data were organized into spreadsheets using the Excel program of the Microsoft Office suite.

\section{Analysis and discussion of results}

With the sales data provided by the bakery it was possible to calculate the daily average sales of $9.73 \mathrm{~kg}$. Knowing that the sales price of the item is $R \$ 21.99 / \mathrm{kg}$ and with the help of the Equation 5 it was possible to find the point of balance of sales with the production itself.

The breakeven point is the point where the minimum quantity is defined. According to Irfana (2012) it is necessary to find the equilibrium point for processing to justify a cost of establishing the industries or the minimum amount of processing necessary to cover the fixed cost Dutra (2010).

$$
E q=\frac{(4.59+48.03)}{21.99-(8.93+3.08)}=5.27[\mathrm{~kg}]
$$

Calculations show that it is necessary to sell $5.27 \mathrm{~kg}$ of cheese bread for the bakery to start making a profit, which corresponds to $54.14 \%$ of the average daily production.

The contribution margin of the item in this first situation, based on Equation 4, is $R \$ 9.98$, which is equivalent to $45.38 \%$ of revenue per kilo Padoveze (2006). 
After opting for outsourcing and with Equation 5 is the new equilibrium point Dutra (2010).

$E q=\frac{(0.73+4.50)}{21.99-9.00}=0.40[\mathrm{~kg}]$

The break-even point is able to indicate where the problem is and how it can be eliminated, because according to Irfana (2012) the break-even point follows the conception of no loss without profit in the fixed and variable cost. Therefore, if the company is operating above the break-even point, the condition is treated as satisfactory and the effort must be made to achieve the highest level of efficiency (Irfana, 2012).

It is important for the company to know the manufacturing cost, as it is the main component of the total cost. Analyze whether a product can be manufactured at a profit and, if so, at what price it should be sold. Therefore, the manufacturing cost assists in the decision to make or buy parts of the product that can be outsourced (Hundal, 1997). With the use of frozen cheese bread, it is necessary to sell $0.40 \mathrm{~kg}$, corresponding to $4.14 \%$ of the average daily production, for the bakery to profit.

The contribution margin of the outsourced item, based on Equation 4, is $R \$ 12.99$, which is equivalent to $59.07 \%$ of revenue per kilo.

$M C=21.99-9.00=\$ 12.99$

The result is in line with the statements of SEBRAE (Serviço Brasileiro de Apoio às Micro e Pequenas Empresas, 2017) that highlight that the sector seeks frozen product options due to the behavior of the modern consumer, who values the speed, functionality and freshness of the products consumed. The contribution margin allows important information for decisionmaking related to the production mix.

Based on the results found, it is noteworthy that from the Direct/Variable Costing Method, it is possible to identify that the cost of the item with own production was $R \$ 64.63$, requiring $54.14 \%$ of the average daily sale to cover fixed costs. With outsourcing, the total cost would decrease to $R \$ 14.23$, requiring only $4.14 \%$ of the average daily sale to then start making a profit. The final cost would decrease to $77.98 \%$.

There are factors to consider during the analysis. The need to categorize retail products for the business decision-making process is emphasized as mentioned by Holý et al. (2017). In addition, also consider the occurrence of food waste due to the performance of operations, as they have negative impacts on the store's performance in terms of costs, reduction of product profit margins (Teller et al., 2018). SEBRAE (Serviço Brasileiro de Apoio às Micro e Pequenas Empresas, 2017) pointed out that due to the limitations in producing large quantities, establishments have sought to offer a smaller menu, but with high productivity, specializing in some bakery products.

\section{CONCLUSIONS}

This objective aimed to demonstrate the importance of applying costing methods to increase the contribution margin as a relevant element for management decision-making, in addition to helping the company to become more competitive against competitors. The research analyzed the 6-month data of a trade retailer in the municipality of Ituiutaba in triângulo mineiro in 2017, at the request of the owner who recognized the need to map the costs of its products. Based on this, we sought alternatives so that bakery items that were more self-sustaining in the long term and competitive against local competitors.

Thus, a theoretical study was carried out based on bibliographic works, with the development of a case study. The tools used Pareto analysis, direct/variable costing method, raw material and energy costs, labor, and contribution merge. In addition, this cost data was 
organized into spreadsheets, using the Excel program of the Microsoft Office suite. Thus, he recognized the points that could be improved in the production processes of his bakery.

Overall, the results of the research highlight that the product cheese bread because its expenses are unknown by the company and are the second best-selling item, with a $9.91 \%$ share of gross revenue stemming from January and June 2017, was the target of study and implementation of outsourcing of the basic raw material. In addition, after using the Direct/Variable Costing Method, it was possible to identify that the cost of the item with its own production was $R \$ 64.63$, requiring $54.14 \%$ of the average daily sale to cover fixed costs. With outsourcing, the total cost decreased to $R \$ 14.23$, requiring only $4.14 \%$ of the average daily sale to then start making a profit. The final cost was decreased by $77.98 \%$.

After the change, the item increased the contribution margin by $30.16 \%$ to $R \$ 12.99$ per kilo sold. The new cost achieved also encouraged the company to study the possibility of lowering the sales price to gain more customers in the region, one of the challenges faced by retailers when implementing a more customer-centric business strategy (Kaplan and Anderson (2007)).

Thus, from the results it is highlighted that the equilibrium point determined the product and quantities necessary to cover all expenses and costs, both fixed and variable. In addition to evaluating and verifying the effects of profitability arising from changes in fixed and variable expenses and costs, sales volume, sales prices, and products sold. Thus, bakeries that manage to dilute their indirect costs are able to practice fairer prices and present a more interesting offer, through the diversification of products and services. In addition, freezing provides the power to diversify production, as well as greater planning.

In summary, the improvement achieved showed the relevance of cost analysis in price formation to increase the company's competitiveness in the Triângulo Mineiro region. Thus, this research offers contributions to academics, with knowledge related to the theme, besides contributing to the bakery sector, being useful for users and interested parties about baking and its costs. In addition, the research seeks or demonstrates the importance of the relationship between costs and sales price. Moreover, it is noteworthy that the effects caused by globalization require a great effort of organizations in the search for effective tools for business support (Carareto et al., 2006).

The study presents as a limitation the fact that the company passes on the costs already established for some products, so that the costs were calculated considering this percentage, as well as other factors ranging from political and economic issues to climatic influences. For future studies, a longitudinal study is suggested to analyze variations in the characteristics of the same sample elements.

\section{REFERENCES}

Assef, R. (2010). Practical guide to price formation: market, tax, and financial aspects for small and mediumsized enterprises, 6th ed., Campus, Rio de Janeiro.

Associação Brasileira da Industria de Panificação e Confeitaria - ABIP (2018a), "Padeiros do Sudeste: região concentra maior números de profissionais do país", available at: https://www.abip.org.br/site/numero-de-padarias-por-estado-2018/ (accessed 7 January 2021).

Associação Brasileira da Industria de Panificação e Confeitaria - ABIP (2018b), “Balanço e tendências do mercado de panificação e confeitaria“, available at: https://www.abip.org.br/site/wpcontent/uploads/2018/03/INDICADORES-E-TENDENCIAS-DE-MERCADO.pdf (accessed 13 May 2020).

Associação Brasileira da Industria de Panificação e Confeitaria - ABIP (2018c), "Indicadores da panificação e confeitaria 2018“, available at: https://www.abip.org.br/site/indicadores-da-panificacao-econfeitaria-brasileira-2018/ (accessed 7 January 2021).

Associação Brasileira das Entidades dos Mercados Financeiro e de Capitais - ANBIMA, (2020), "Xray investor", available at: https://www.anbima.com.br/data/files/AE/31/E6/CB/52A356107653 125678A80AC2/Relatorio-Raio-X-Investidor-PT.pdf (accessed 3 March 2020).

Barbosa, M.B., Palma, D., Bataglin, T. et al. (2007), "Cost of food in the first year of life", Nutrition Journal, Vol. 20, No. 1, pp. 55-62. 
Bruni, A.L. and Famá, R. (2010). Gestão de custos e preços: com aplicativos na calculadora HP $12 C$ e Excel, Atlas, São Paulo, vol. 5.

Carareto, E.S., Jayme, G., Tavares, M.P.Z. et al. (2006), "Strategic cost management: costs in decision making", UEG Economics Journal, Vol. 2, No. 2, pp. 1-24.Corrêa, H.L. and Corrêa, C. (2012), Production and Operations Administration - Manufacturing and Services. 3rd ed., Editora Atlas, São Paulo.

Carelli, R. L. (2004), Atypical Forms of Work, LTr, São Paulo.

Cardoso, L. V., Neto, F. J. K., Denicol, J., et al. (2017). “Um sistema de custeio para apoio à precificação em uma empresa de transporte rodoviário internacional", Produção em Foco, Vol. 7, No. 1, pp. 142-168.

Department of Research and Economic Studies - DEPEC (2017), "Supermarkets", Bradesco, available at: https://www.economiaemdia.com.br/EconomiaEmDia/pdf/infset_supermercados.pdf (accessed 10 September 2017).

Dutra, R.G. (2010). Costs: a practical approach, Atlas, São Paulo.

Hayes, R.H. and Wheelwright, S.C. (1984), Restoring our Competitive Edge: Competing Through Manufacturing, Wiley, New York, vol. 8.

Hill, T. (1985), Manufacturing Strategy, Open University Press, Milton Keynes.

Hirschman, A. O. (1958), The Strategy of Economic Development, Yale University Press, New Haven.Holý, V., Sokol, O. and Černý, M. (2017), "Clustering retail products based on customer behavior", Applied Soft Computing, Vol. 60, pp. 752-62.

Holý, V., Sokol, O. and Černý, M. (2017), "Clustering retail products based on customer behaviour", Applied Soft Computing, Vol. 60, pp. 752-62.

Hundal, M.S. (1997), "Product costing: a comparison of conventional and activity-based costing methods", Journal of Engineering Design, Vol. 8, No. 1, pp. 91-103.

Instituto Brasileiro de Geografia e Estatística - IBGE (2017), "IBGE indicators: monthly trade survey - June 2017", available at: ftp://ftp.ibge.gov.br/Comercio_e_Servicos/Pesquisa_Mensal_de_Comercio/Fasciculo_Indica dores_IBGE/pmc_201706caderno.pdf (accessed 10 September 2017).Instituto Tecnológico da Panificação e Confeitaria - ITPC (2018), "Performance projection of bakers and brazilian confectioneries in 2017", available at: http://institutoitpc.org.br/indicadores-do-setor/ (accessed 13 May 2020).

Instituto Tecnológico de Panificação e Confeitaria - ITPC (2018), “Performance Projection of Bakers and Brazilian Confectioneries in 2017", available at: http://institutoitpc.org.br/indicadores-do-setor/ (accessed 13 May 2020).

Irfana, KD (2012). Produção e rentabilidade de produtos de confeitaria de farinhas em diferentes portes da Indústria de Panificação na região de Marathwada (MS) Índia. Repórter de Pesquisa Científica, Vol. 2, No. 2.

Jeje, K. (2020), "Risk-taking and performance of small and medium-sized enterprises: lessons from Tanzanian bakeries", Journal of Economics and Behavioral Studies, Vol. 12, No. 3, pp. 1-22.Kaplan, R.S. and Anderson, S.R. (2007), Custeio Baseado em Atividade e Tempo, Elsevier, Rio de Janeiro.

Konstantas, A., Stamford, L. and Azapagic, A. (2019), "Economic sustainability of food supply chains: life cycle costs and value added in the confectionary and frozen desserts sectors", The Science of the Total Environment, Vol. 670, pp. 902-14.

Lima, E.B. (2014), Cost Accounting, Conselho Regional de Contabilidade do Estado do Rio de Janeiro, Rio de Janeiro.

Lu, L. and Reardon, T. (2018), "An economic model of the evolution of food retail and supply chains from traditional shops to supermarkets to e-commerce", American Journal of Agricultural Economics, Vol. 100, No. 5, pp. 1320-35.

Martins, E. (2008), Cost Accounting, 9th ed. Atlas, São Paulo.Moreira, D.A. (2008), Production Management and Operations, 2nd ed., Cengage Learning, São Paulo.

Padoveze, C.L. (2015), Basic Cost Accounting Management Course, 2nd ed., Cengage Learning, São Paulo.

Porter, M.E. (1989), Competitive Advantage: Creating and Sustaining Superior Performance, Campus, Rio de Janeiro.

Prodanov, C.C. and Freitas, E.C. (2013), Methodology of Scientific Work: Methods and Techniques of Research and Academic Work, 2nd ed., Feevale University, Novo Hamburgo. 
Reiner, G., Teller, C. and Kotzab, H. (2013), "Analyzing the efficient execution of in-store logistics processes in grocery retailing-The case of dairy products", Production and Operations Management, Vol. 22, No. 4, pp. 924-39.

Rocha, I.C., Oliveira, A.M., Soares, F.I.L. et al. (2019), "Cost acoounting as a tool in sales price formation in a bakery industry", Brazilian Journal of Development, Vol. 5, No. 9, pp. 15957-80.Roesch, S.M.A. (2003), Internship and Research Projects in Administration: Internship Guides, Conclusion Papers, Dissertations and Case Studies, 3rd ed., Atlas, São Paulo.

Roncato, A.G. (2015), Determination of production costs in a bakery industry (Specialization in Finance) School of Administration, Federal University of Rio Grande do Sul (UFRGS). Available in: http://hdl.handle.net/10183/142119

Serviço Brasileiro de Apoio às Micro e Pequenas Empresas - SEBRAE (2017), Estudo de Tendências. Perspectivas para Panificação e Confeitaria, disponível em: <https://www.sebrae.com.br/sites/PortalSebrae/bis/um-estudo-sobre-panificacao-biscoitos-econfeitaria,7084ee1e19042510VgnVCM1000004c00210aRCRD> <https: // bibliotecas sebrae.com.br / chronus / ARQUIVOS_CHRONUS / bds / bds.nsf / 4AC5C034FC7F782E83257630053107A / \$ File / NT0004207E.pdf

Slack, N. (1993), Competitive Advantage in Manufacturing, Atlas, São Paulo.

Teller, C., Holweg, C., Reiner, G. et al. (2018), "Retail store operations and food waste", Journal of Cleaner Production, Vol. 185, pp. 981-97.

Walton, M. (1989), The Deming Method of Administration, Marques Saraiva, Rio de Janeiro.

Wernke, R. (2017), Analysis of Costs and Sales Prices, 11 th ed. Saraiva, São Paulo.

Author contributions: Alexsandro S. Solon: Writing-Theoretical background, Methodological procedures, Results analysis; Flávia Barbosa Araújo: Writing-Introduction, Writing-Theoretical background, Methodological procedures, Data collection, Results analysis; Fernando de Araújo: Project Management, Writing-Introduction, Results analysis. 